\title{
Implementation of Cooperation Agreement Between the Ministry of Internal Affairs, Police, Attorney General Office (Ago) in Handling and Crime Of Corruption in Indonesia
}

\author{
Cipto Dwi Leksana ${ }^{1}$ and Rakhmat Bowo Suharto ${ }^{2}$
}

\begin{abstract}
Corruption in Indonesia at this time, is already in a position of very severe and so deeply rooted in every facet of life. The development of corrupt practices from year to year is increasing, both in quantity or amount of losses to the state and in terms of the quality of the increasingly systematic, sophisticated and scope has expanded in all aspects of society. Increased corruption uncontrolled will bring disaster on the lives of not only the national economy but also the life of the nation in general. Rampant corruption cases in Indonesia, no longer know the limits of who, why, and how. Not only office holders and the interests of who committed the crime of corruption both in the public and private sector, but corruption has become a phenomenon. Cooperation Agreement between the Ministry of Internal Affairs, the Attorney General and the Police into a new breakthrough in creating a legal product that provides a form of cooperation among government agencies in combating corruption in Indonesia from all sectors of the country.

Keywords: Cooperation Agreement; Crime; Corruption.
\end{abstract}

\section{Introduction}

Clean state administration to be important and highlynecessary to avoid corrupt practices that do not only involve the relevant authorities, but also by his family and cronies, which if left unchecked, then the people of Indonesia will be the most disadvantaged position. According to Nyoman Serikat Putra Jaya says that corruption is not only done by state officials, among state officials, but also the organizer of the state with other parties such as family, cronies and businessmen, thus undermining the foundations of society, nation and the state, as well as endanger the existence of the state. $^{3}$

Corruption has become a sort of phenomenon of everyday life in Indonesia. Various institutions, actions, and assessment against cultivated in a big action sequence that normally exist in the title of "fighting corruption". In line with these efforts, the skepticism it propagates in every action and discourse of eradication of corruption, whether they are critical or constructive supporters or fighters of the anti-corruption,

\footnotetext{
${ }^{1}$ Student of Master of Law, Universitas Islam Sultan Agung Semarang and Members of the Indonesian National Police (Polri), email: akbpcipto@gmail.com

${ }^{2}$ Faculty of Law Universitas Islam Sultan Agung

${ }^{3}$ Nyoman Serikat Putra Jaya, 2005, Tindak Pidana Korupsi, Kolusi dan Nepotisme di Indonesia, Semarang, Badan Penerbit Undip, p. 32.
} 
as well as debilitating politically from elite circles who feel threatened collusive interests. It shows that the affairs of law enforcement corruption at all-time is not the intent or accomplishments KPK (Corruption Eradication Commission) alone, but also responsibilities of various parties, ranging from institutions advocacy and monitoring, legal institutions that exist, to the public Indonesia itself.

The Corruption Eradication Commission (KPK) stated that there 5 (five) points prone to corruption, namely (1) the planning and implementation of Budget (APBD), (2) the procurement of goods and services, (3) a lack of oversight, (4) human resources management, and (5) the licensing or services public. The vulnerable points are made up of several sectors in the government and see that the Commission is not able to carry out surveillance and eradication itself, it takes the cooperation of the various agencies with regard to the fifth point. Because the so-called corruption in the government will inevitably lead to a loss for the country not only in central government but also in local government. In this case the agency will widen the cooperation of more stringent supervision to the regions.

The role of law enforcement officials, especially the Indonesian National Police (Polri) and the Attorney General's Office (Kejagung/AGO) as judicator countries took part in carrying out the eradication of corruption which also required cooperation with the government's internal control apparatus (APIP) in this case the Ministry of Internal Affairs (Kemendagri/MOHA) in the fight against corruption to the regions. The number of cases of corruption committed by the head of government invited the region to find a way out.

In the form of the increase, on February 28, 2018 held signing of cooperation or Memorandum of Understanding (MoU) between the Ministry of Internal Affairs, the Police and the Attorney General's handling of public complaints over alleged corruption in local government. The cooperation agreement was signed by the Inspector General of the Ministry of Internal Affairs of Sri Wahyuningsih Kabareskrim Komjen/Commissioner General Ari Dono Sukmanto and the Deputy Attorney General for Special Crimes Adi Toegarisman. On this occasion, Ari Dono hope the cooperation between APIPs (Government Internal Supervisory Apparatus) and APH (law enforcement authorities) in the handling of corruption.

Seeing the cooperation agreement, many proponents but few who respond to negative the existence of agreement between the countries in the implementation of the handling of corruption cases. Because of the negative feedback arising from the assumption that the rules in the agreement has the potential to hit Article 3 of Act No. 31 of 1999 on Corruption Eradication which in the article reads: "Everyone with the intention of enriching himself or another person, abuse of authority that could harm the state, can be imprisoned". ${ }^{4}$

But basically related to the cooperation agreement has limitations which the rules of a memorandum of understanding remains beracu at a higher rule hierarchies that rule of

\footnotetext{
${ }^{4}$ Article 3 of Act No. 31 of 1999 on Corruption Eradication.
} 
law. In this case the discussion and analysis of the cooperation agreementbetween the Ministry of Internal Affairs, the Police and the Attorney General related to the handling of public complaints over alleged corruption in the local government can provide an understanding of the important role of the cooperation agreement.

Based on the background described above can be formulated problem in this research are: 1) How implementation of the cooperation agreement between the Ministry of Internal Affairs, Police, and the Attorney General in the handling of corruption in Indonesia ?; 2)What are the strengths and weaknesses in the implementation ofa cooperation agreement between the Ministry of Internal Affairs, the police, and the Attorney General's handling of corruption in Indonesia?

\section{Research methods}

To conduct the assessment in this study the authors used socio-juridical methods. Researchers tried to do research in a scope on communications of an individual which obtained the data from an individual is descriptive without giving any statement or additions that nature can damage the background of the individuals studied holistically but researchers must act and view it as part of a integrity.

\section{Results and Discussion}

\subsection{Implementation of the Cooperation Agreement between the Ministry of Internal Affairs, Police and the AGO in Handling of Corruption in Indonesia}

Corruption is a violation of the rights of social and economic rights of the people, so that corruption can be classified as an extraordinary crime. Therefore its eradication should also be done in a way that was incredible as well (extra-ordinary enforcement). According to Romli Atmasasmita, that: ${ }^{5}$

"Corruption in Indonesia has been an extraordinary crime, so that the demands of the availability of legal devices is extraordinary and sophisticated and institutions dealing with corruption is not inevitable. Indonesian people would agree that corruption must be prevented and eradicated from the ground water, because corruption has proven to be very miserable people even own an infringement of economic and social rights of the people of Indonesia ".

The problem of corruption and dissect the problem is something very urgent, because corruption is almost always associated with power and authority as well as the people involved in it. Moreover, corrupt practices usually performed in the form of engineering that seems justified by the law and there are even legal manipulation. This

\footnotetext{
${ }^{5}$ Romli Atmasasmita, 2002, Korupsi, Good Government dan Komisi Anti Korupsi di Indonesia, Badan Pembinaan Hukum Nasinal Departemen Kehakiman dan Hak Asasi Manusia Republik Indonesia, Jakarta, p. 25.
} 
kind of thing is also associated with certain governance principles, to be able to affect the credibility and capability of the government. ${ }^{6}$

To ensure the power possessed by each state officials will be implemented in accordance with the grounds for granting the power itself and prevent not the abuse of power, the administration and operation of the power it has to be based on the law. This is the meaning of the rule of law both in the context rechtsstaats and the rule of law. The law became software directing, limiting, and controlling the implementation of state. ${ }^{7}$

The Ministry of the Interior, Bureau of Criminal Investigation, Police Headquarters, and the Attorney General have signed a Memorandum of Understanding (MoU) or a cooperation agreement on the handling of complaints related to indications of corruption on February 28, 2018. The purpose of the signing of a cooperation agreement in the area of corruption complaint one of them is to strengthen the commitment to the prevention of corruption, with the establishment of synergies between Government Internal Supervisory Apparatus (APIP) with law enforcement authorities (APH).

Related to the implementation of the prevention and eradication of corruption, APH, the Prosecutor and the Police have their own mechanism. However, seeing the urgency of eradicating corruption, the Ministry of Internal Affairs deems it necessary to establish a synergy between the Ministry of Internal Affairs, in this case APIPs, with $\mathrm{APH}$. related This corruption complaints cooperation agreement itself, the principle is mutual respect and can not intervene in the authority of each institution.

As for the implementation of this agreement for the coordination mechanism, when it appeared the public complaints about alleged corruption, the Police Criminal Investigation will coordinate in advance with the APIP, then APIPs researching into. If after investigation found the allegations is an administrative violation, it will be followed up internally institutional. However, if these allegations constitute a criminal offense then APIPs will submit to the Commission, the Attorney General, or the Police. Thus, APIPs role as a deterrent to run well. When the alleged administrative violations have been detected, APIPs can immediately remind heads of regions concerned. This mechanism is expected to reduce the budget investigations should be issued by APH, as well as accelerate the process of investigation. On the other hand, strengthening APIPs through this agreement can also give security to the State Civil authorities (ASN) and the head of the region, for no fear shall be punished when making policy and new innovations.

\footnotetext{
${ }^{6}$ Asrianto Zainal, Penegakan Hukum Tindak Pidana Korupsi Oleh Kejaksaan, Jurnal Hukum, IAIN Kendari, 2017, p. 2.

${ }^{7}$ Andi Supratman, Ediwarman, M.Hamdan, Edi Yunara, Analisa Hukum Pemberantasan Tindak Pidana Korupsi Dalam Perspektif Psikologi Kriminal, USU Law Journal, Vol.5 No.1, 2017.
} 


\subsection{Strengths and Weaknesses in Implementation Cooperation Agreement Between the Ministry of Internal Affairs, Police, and the Attorney General for Handling of Corruption in Indonesia}

Within the framework and scope of the reforms that have taken place in this country, people are increasingly made aware of the important role of law as a means of patronage (social defense) in regulating the life of society, nation and country in various aspects of life such as politics and economics. Legal role as protector reflected melalai legal function as a means of social control, social changes (social engineering) and the law as a means of integrative. ${ }^{8}$ For the Indonesian nation constitutionally, the law serves as a means to uphold the democratic life, social justice upholds life and uphold humane life.

Cooperation Agreement between the Ministry of Internal Affairs, the Attorney General and the Police in handling corruption becomes a separate law as a breakthrough in law enforcement base on fairest justice. But there is no doubt that the new legislation will bring up the pros and cons on the creation of these rules. Weaknesses also appear when viewed from several sides and effects. But also laws are not created to harm, not to destroy, not to side with the door but the main purpose is sure to create legal certainty and fairness are essential, with behind the existing weakness also emerged advantages of a legal product.

Objective signing of the Cooperation Agreement in the area of corruption complaints salahsatunya is to strengthen the commitment to the prevention of corruption, with the establishment of synergies between APIPs with APH.One of the points that in the Cooperation Agreement is their authority to react APIPs internal corruption institutions before transferred to law enforcement authorities (APH) in this case, police and prosecutors. This point was later polemical, because on one side of this rule is a form of authority APIPs increase, and the implementation of the mandate of Act No. 30 of 2014 on Government Administration and Act No. 23 of 2014 on Regional Government. On the other hand, this rule is considered to weaken the role of APH in react corruption, as well as "liberating" corrupt, because APIPs considered not neutral and still have a strong intervention from local officials.

Thus the Cooperation Agreement are being debated among the people due to lack of the strong position that could potentially be passed APIPs officials or local officials who indicated corruption under the pretext that his actions violated only administrative action. Moreover, their flexibility in performing surveillance and law enforcement against corruption. This saw one of the points of the Cooperation Agreement which deals with the government likely to carry out acts of corruption can be considered punishment it receives if the person concerned can restore the amount of money that was corrupted and is considered detrimental to the state.

\footnotetext{
${ }^{8}$ Sajipto Raharjo, 1983, Hukum Dan Perubahan Sosial, Bandung, Alumni, p.127.
} 
With the positive goals, in fact complaints of corruption enforcement mechanisms agreed upon in the Cooperation Agreement is still doubt about the effectiveness of implementation. One is a clause in the Cooperation Agreement that allegedly can be a wide opening for the passage of the corruptors area is Article 7 point $b$ (the Cooperation Agreement) which reads "There is a loss to the state or region and have been processed through compensation claims or demands of the treasury no later than 60 days from the examination report Government Internal Supervisory Apparatus (APIP) or the Financial Supervisory Agency (BPK) received by officials or have been acted upon and declared completed by APIPs or CPC. " This article regulates when officials or government officials found guilty of corruption and he then paid the compensation amount of the proceeds of corruption then it is completed in other words free from criminal charges. It is against the Law of Corruption Act No. 31 of 1999 Article 4, which reads "The return losses to the state or state economy does not eliminate criminal as referred to in Article 2 and Article 3".

Not optimal APIPs role, due to the lack of regulation of higher (Government Regulation or the Act), also opens up the potential for abuse of authority by APIPs to "liberate" or ASN local officials who actually committed the crime of corruption. APIPs role in such mechanisms as the first gate to perform screening on the complaints of alleged corruption by local officials from the public will be confronted with a subordinate position as Regional Head. The potential of "collusion" between HR APIPs with ASN or local officials to stop investigation on the complaints of alleged corruption would be wide open.

In addition, the number of parties involved in the care of a complaint of corruption are also worth considering, with the involvement of APIPs course makes APH can not directly act in investigating the complaint which is feared will prolong the process of investigation and overlapping rulesin charge of the case, it could be the foundation of the "blanket" for perpetrators to argue that corruption has to do is act of mere administrative violations. Related to this, the Inspectorate General of the Ministry of Internal Affairs has given an explanation that if someone has determined a suspect or caught in the corruption, the criminal proceedings continued and can not be classified administration although concerned has made the country's financial returns.

However, with the signing of the Cooperation Agreement is a great role APIPs can build a good system of corruption prevention, especially in the regions. During this time, it structurals APIP was under the regent or governor. This is then make trouble when the alleged violations by the head region.

\section{Closing}

\subsection{Conclusion}

From the background in terms of objective research that the cooperation agreement between the Ministry of Internal Affairs, the Attorney General and the Police, one of 
which is to strengthen the commitment to the prevention of corruption, with the establishment of synergies between Government Internal Supervisory Apparatus (APIP) with law enforcement authorities (APH). As for the implementation of this agreement for the coordination mechanism, when it appeared the public complaints about alleged corruption, the Police Criminal Investigation will coordinate in advance with the APIP, then APIPs researching into. If after investigation found the allegations is an administrative violation, it will be followed up internally institutional. However, if these allegations constitute a criminal offense then APIPs will submit to the Commission, the Attorney General, or the Police. Thus, APIPs role as a deterrent to run well. When the alleged administrative violations have been detected, APIPs can immediately remind heads of regions concerned. This mechanism is expected to reduce the budget investigations should be issued by $A P H$, as well as accelerate the process of investigation. On the other hand, strengthening APIPs through this agreement can also give security to the State Civil authorities (ASN) and the head of the region, for no fear shall be punished when making policy and new innovations.

Cooperation Agreement between the Ministry of Internal Affairs, the Attorney General and the Police in handling corruption becomes a separate law as a breakthrough in law enforcement base on fairest justice. But there is no doubt that the new legislation will bring up the pros and cons on the creation of these rules. Weaknesses also appear when viewed from several sides and effects. But also laws are not created to harm, not to destroy, not to side with the door but the main purpose is sure to create legal certainty and fairness are essential, with behind the existing weakness also emerged advantages of a legal product.

\subsection{Suggestion}

Regulations to ensure the independence and accountability of APIPs need to be legalized. Strengthening the role APIPs related regulations, including changes that are above structurals APIP Regional Head is being formulated. Expected future regulations to be made in the form of Government Regulation (PP) or Act (the Act).

Preferably both APIPs and APH still refer to Act No. 20 of 2001 on combating corruption in making a deal, as well as actions related condemnation of corruption in order to create a strong legal entity. Cooperation between the various parties of the Ministry or the Institute in an effort to encourage the creation of a legal order is certainly an action that should be done but agreed in the joint must not conflict with the supreme laws that have been enacted. Therefore, it is necessary review of complaints of corruption cooperation agreement with the Commission consider the defenders' participation in making an agreement on corruption.

\section{Bibliography}

[1] Asrianto Zainal, 2017, Penegakan Hukum Tindak Pidana Korupsi Oleh Kejaksaan, Jurnal Hukum, IAIN Kendari. 
[2] Nyoman Serikat Putra Jaya, 2005, Tindak Pidana Korupsi, Kolusi dan Nepotisme di Indonesia, Semarang, Badan Penerbit Undip.

[3] Romli Atmasasmita, 2002, Korupsi, Good Government dan Komisi Anti Korupsi di Indonesia, Badan Pembinaan Hukum Nasinal Departemen Kehakiman dan Hak Asasi Manusia Republik Indonesia, Jakarta.

[4] Sajipto Raharjo, 1983, Hukum Dan Perubahan Sosial, Bandung, Alumni.

[5] Act No. 31 of 1999 on Corruption Eradication.

[6] Andi Supratman, Ediwarman, M. Hamdan, Edi Yunara, Analisa Hukum Pemberantasan Tindak Pidana Korupsi Dalam Perspektif Psikologi Kriminal, USU Law Journal, Vol.5 No.1, 2017. 